\title{
Revitalizing Alfred Adler: An Echo for Equality
}

\author{
Mary C. McCluskey ${ }^{1}$ (D)
}

Accepted: 1 February 2021 / Published online: 5 March 2021

(C) The Author(s), under exclusive licence to Springer Science+Business Media, LLC part of Springer Nature 2021

\begin{abstract}
The work of Alfred Adler's Individual Psychology arguably applies to contemporary social work practice and education. The tenets of Individual Psychology are reviewed in the context of a historical sketch of Adler's work as a medical doctor, psychoanalyst, and colleague of Freud. His eventual divergence from psychoanalysis to begin his own psychological and education movement which focused on social reform is emphasized. Individual Psychology is examined in detail including original case examples demonstrating his influence on and compatibility with contemporary social work theories. Empirical evidence is provided supporting present-day application of his theory. Adler serves as a much-needed example of a professional who successfully and simultaneously advanced both the micro and macro world of mental health. Adler's contribution deserves to be explicitly included in social work curricula.
\end{abstract}

Keywords Adler $\cdot$ Individual psychology $\cdot$ Society $\cdot$ Inferiority complex $\cdot$ Child guidance centers $\cdot$ Social reform $\cdot$ Equality

Individual Psychology does not condemn, but endeavors to improve; it takes the blame from the individual's shoulders and assigns it to failures of our civilization, in whose imperfections all of us are implicated, and it demands co-operation for their removal. (Adler 1938, p. 104)

\section{Introduction}

During these highly divisive and turbulent times in current society, the somewhat forgotten wisdom of Alfred Adler and his Individual Psychology movement comes to mind, and seems to beg for a reincarnation of the dialogue which was largely shut down by the Nazi regime. Adler's work was, in part, an educational movement geared towards bringing people together with its emphasis on the healing power of connection. He found that "false individualism" is at the heart of neurosis and that society as a whole suffers from this faulty ideal (Adler 2013b/1930, p. 29). This article is intended as an exploration of Alfred Adler's Individual Psychology and argues why it should be explicitly taught in social work curricula.

Mary C. McCluskey

mm649@nyu.edu

http://marymccluskeydsw.com

1 NYU School of Social Work, New York, NY, USA
While Adler and his teaching seem to be woven into actual social work practice, his ideas seem to have become so diffuse that very little seems to be attributed to him. Ellenberger (1970) wrote, "It would not be easy to find another author from which so much has been borrowed from all sides without acknowledgement than Alfred Adler" (p. 645). This sentiment was shared as early as 1939 , when Wittels wrote, "The field of 'social' etiologies was the exclusive object of Alfred Adler's research, and although his heirs roarely quote him, the 'new' discoveries in this field are based on his theories. For this reason I call this school which is now in formation the Neo-Adlerians" (1939, p. 433). Wittels was referring to the interpersonal school, also known by most as the Neo-Freudians. The importance of Adler's work has been largely neglected, and while there do exist Adlerian schools today, their influence is not mainstream. This is especially unfortunate for the field of social work, as Adler's ideology seems to be born out of societal ills and directly address their prevention. Ansbacher (1992) labeled Alfred Adler a "pioneer in the prevention of mental disorders" (p. 3). This article will attempt to not only illuminate Adler's contributions, but to show how his many principles are shared within the field of social work, and how social workers and society, as a whole, can directly benefit by familiarizing themselves with Adler's Individual Psychology ideas.

Cushman's ideas fully support Adler's idea that false individualism is at the heart of all societal ills. He argues that 
we have a moral obligation to examine the historical roots of psychotherapy. Cushman says, "If we situate psychotherapy historically, we might be able to develop social practices that will shape a slightly new configuration of the self, one that will be comprised of new moral understandings and capable of developing new political and economic structures, structures that could lessen the country's capacity to injure and destroy its own citizens and those of other nations" (Cushman 1995, p. 24). This author contends that Alfred Adler is an important part of that history.

At a time when society, especially the profession of social work, is examining and trying to combat white supremacy and looking to current scholars who are advocating for change, we would be wise to listen to what Adler had to say almost a century ago, "All institutions, our traditional attitudes, our laws, our morals, our customs, give evidence of the fact that they are determined and maintained by privileged males for the glory of male domination" (Adler 1927, p. 123). Todman and Mansager (2011) espouse that the topic of social exclusion needs to be an interdisciplinary dialogue and sees how a "innovative Adlerian philosophical thought-stream" (p. 95) can help link the professions in an effort to combat social injustice. This author argues that the social work profession should be in the forefront of such discussions.

Adler was a feminist who fought for social reform; this was the reason for his break with Sigmund Freud and psychoanalysis (Bankart 1997). That said, in fighting for reform, Adler did not abandon clinical work, in fact, he created his own complete psychology which explicitly valued social justice. Adler is a stellar example of a professional who successfully embraced and advanced both the micro and macro world of mental health, something social work students often struggle to understand as possible. Adler's Individual Psychology is part of the required curriculum for masters of psychology students (Sommers-Flanagan and Sommers-Flanagan 2012; Corey 2017). Bankart purports (as cited in Sommers-Flanagan and Sommers-Flanagan 2012), "Adler's influence on the developing fields of psychology and social work is incalculable" (p. 146). Why should social work students be deprived of the wisdom of Alfred Adler? His contributions are perfectly aligned with the ideals and mission of the social work profession.

Throughout this article, illustrations of Adler's Individual Psychology in both its historical and modern context will be illuminated. Theories that social workers embrace including social learning theory and systems theory can be linked to Adler (Balla 2019). Also examined will be ways in which Adlerian psychology compliments contemporary theories of social work, including attachment, object relations, and interpersonal theories. Research studies including an evidence-based Adlerian play therapy (AdPT) (Meany-Walen 2020); an Adlerian video-based treatment for African American parents (Farooq et al. 2005); the Parent Reunification Model (La Guarda and Banner (2012), and the Adlerian Parent Training programs (Fashimpar 2000) will be examined. Finally, this article will show how one of Adler's main concepts, "the inferiority complex" was instrumental in advancing civil rights as can be gleamed in the following quote by Clark (as cited in Griffith and Powers 1984): " To the extent that Adlerian thinking influenced my own thinking and research, and ... that my thoughts and writings have influenced in any way the civil rights movement, determines, at least in part, the extent to which the ideas of Alfred Adler have contributed to the accelerated quest for racial justice in America" ( $p$. $30)$.

\section{Who was Alfred Adler?}

Adler was a medical doctor and psychoanalyst who Hirsch (2005) contends that before World War I, was the second most significant intellectual after Sigmund Freud. Adler was known to be outgoing and gregarious. He enjoyed sitting for hours with friends and colleagues at Café Dom in Vienna, passionately debating philosophical and social ideas (Hoffman 1994). While Adler and Freud were affiliated for close to a decade, Adler was not a student of Freud (Ellenberger 1970; Lantz 1980; Makari 2008) and eventually his own ideas became too incompatible with Freud's psychoanalysis and their paths diverged. Whereas Freud hewed to a theoretical orientation centered on the individual instinct and biology, Adler leaned towards appreciation of how societal concerns and family dynamics shaped the individual.

Alfred Adler was born in a Vienna suburb on February 7,1870 . His family was lower-middle class and from Jewish descent. Adler was the second child in his family, and had an older brother whom he always felt inferior to. $\mathrm{He}$ had many younger siblings, including one who died at a young age; this traumatic experience is one of the reasons he decided to become a doctor. The other experience that informed this decision was Adler's poor health as a child; he suffered from rickets and had breathing and mobility problems (Ellenberger 1970). Adler completed medical school and developed his practice serving predominantly the poor. Adler's first published ideas were in the field of social medicine, as he believed much of disease to be a product of society. His monograph was called Health Book for the Tailor Trade; in this monograph he calls for new labor legislation to ensure improved working conditions that he believed would decrease disease among tailors (Ellenberger 1970). Adler was said to be a socialist but rejected any affiliation with the 
communist movement. Adler's focus on social medicine was in play years before he joined Sigmund Freud's Wednesday night discussion group, and the psychoanalytic movement. His initial presence was eventually replaced by his all-consuming drive to educate the public on the teachings of his Individual Psychology (Ellenberger 1970).

Adler's first book on organ inferiority was valued by Freud, and complimented his ideas; while Adler did not originate the concept of organ inferiority, he was the first to develop a systematic theory around it (Ellenberger 1970). This concept explained that neurosis can develop when a person's organs are not fully functional, and their physical limitations make them feel inferior, thus they develop maladaptive ways of compensating for this lack. While for a time, an admiration and respect existed between Freud and Adler, their affiliation was severed in 1911. Their irreconcilable differences can be seen in Ansbacher's statement, "The theory of sexuality of Alfred Adler is best characterized as the opposite of Freud's. Whereas Freud believed a person's sexuality determines his personality, Adler asserted that the total personality, the style of life, determines the sexuality" (Adler 1982, p. v). In essence, Adler replaced Freud's libido with aggression (Ellenberger 1970, Makari 2008). Adler believed that rather than being driven by pleasure, people are driven by an aggressive need to overcome their sense of inferiority. While Adler believed in the unconscious, he also looked closely at conscious behaviors to determine an individual's life goal. He felt that instead of being victims of their inner drives, that people actually have choices (Adler 2013b/1930, O'Connor 1992); a critical task of Individual Psychology is to help people to see these choices. While Individual Psychology grew to be something very different than psychoanalysis, both influenced the other in important respects. Adler's work stresses the importance of early childhood, something he attributed as originating from Freud. He also learned from Freud the importance of dreams. Individual Psychology uses dreams to uncover a person's unconscious goals. Adler also influenced Freud, though it is unclear whether or not Freud ever admitted this. Freud vehemently dismissed Adler's theory of aggression, yet years later he adopted his own theory of aggression in the death instinct (Ellenberger 1970). While Freud and Adler went their separate ways, and Freud's psychoanalysis would eventually become a grand theory, Adler enjoyed his own success for a significant period of time. This success was fed by the political situation after World War I.

The climate of the time, particularly the collapse of the Austrian-Hungarian Empire, supported Adler's teaching and transformed his work into a socio-ethical movement that had worldwide reverberations (Ellenberger 1970). Ellenberger (1970) contends the years between 1920 and 1934, before the Nazi suppression of socialism, were Adler's most successful years. After the World War I defeat of Austria, the
Social Democrats came to power, paving the way for the implementation of Adler's ideas. The new political state instituted new welfare institutions with a particular focus on educational reform; this political climate allowed Adler and his associates to establish twenty-eight child guidance clinics by 1930 (Adler and Associates 2013/1930), making Vienna the first city in the world where school children had access to free educational therapy (Ellenberger 1970).

Adler's past popularity has faded, and his contributions are often unrecognized, his work swept up in the psychiatric deluge of the time (Borenzweig 1971). That said, it appears that Adler's work informed many diverse practice genres including: prevention, ego psychology, child guidance, cognitive theory, social action, group and family therapy, day treatment programs, multiple therapy, and the development of more effective education methods (Lantz 1980). Adler's approach is very strengths-based, practical, and trauma-informed.

\section{Adler's Individual Psychology}

While an exhaustive look at Individual Psychology is beyond the scope of this paper, I hope to highlight the most pertinent contributions and how they might be utilized by social workers today. Adler coined his own psychology, "Individual Psychology" that many consider to be a psychology of values (Stein 2014). The mission of the social work profession is also very much rooted in a set of core values. Throughout this paper, I hope it will become clear how Adler's own actions and values reflect those of the National Association of Social Workers' core values: service, social justice, dignity and worth of the person, importance of human relationships, integrity, competence (1996/2008).

The name Individual Psychology stems from Adler's belief in the uniqueness of every individual. All of his interventions considered the nuances of each person he treated. He cautioned the use of classifications systems as anything more than a guide as he did not feel humans should be pigeonholed into classifications (Adler 2013b/1930). Ironically, the name, Individual Psychology, belies its underlying premise that people are inherently shaped by their environment. Adler was admittedly an idealist, and his psychology aimed at bringing people together, as is evident in the statement, "We are approaching a time where everyone will take his place as an equal, self-reliantly and freely, no longer in the service of a person, but in the service of a common idea" (Adler 1964, p. 55). Adler spoke out vehemently against the marginalization of minority groups, campaigned for women's social equality and predicted both the Women's liberation and Black Power movements (Watts and Pietrzak 2000). According to Miller (1973) and Jordan (2010), Adler was the first psychoanalyst to condemn society's conception 
of women, as well as illuminate its cause in the psychological problems of women and children. These conceptions led to feelings of false inferiority; Adler espoused that masculine dominance was unnatural (Adler 1927) and "the historical movement of humanity is to be regarded as the history of its feelings of inferiority and of its efforts to find a solution of its problems" (Adler 1938, p. 97). Social equality was considered by Adler to be the ideal, and the solution to the problems of humanity. If everyone was treated equally, then people would work together, instead of trying to constantly compete and their efforts would be less focused on neurotic self-interest and trying to prove their own worth; instead they would use their energies to contribute to society. Individual Psychology endeavors to help people become more productive and connected in their lives, specifically in three areas: society, work and love.

Adler was careful not to pathologize people. He felt that those who struggled with neurosis and psychosis had difficulty coping with life because they had become deeply discouraged. Adler identified many ways in which a person can become discouraged in life. The aforementioned organ inferiority is just one way that a child may feel inferior and disconnected; in addition, abuse and neglect, as well as poor family guidance, can cause these feelings (Adler and Associates 2013/1930). Perhaps it is counterintuitive, but a group Adler considered to be at high risk of becoming discouraged was what he referred to as "pampered children." Adler (2013c/1930) said, "The mere fact that children are pampered is sufficient to generate in them a feeling of inferiority and to deprive them of self-confidence", (p. 131). He believed they would suffer feelings of inferiority, as they believe that the world revolves around them, until they begin school. At school, they are faced with reality, and often, have difficulty adjusting. The belief that they should, and, even need to be taken care of, coupled with a sense of entitlement, discourages their sense of creativity, initiative, and especially courage, to be a contributing member of society. Instead, Adler found, they strive for superiority, rather than learning to cooperate. The "inferiority complex" is what Adler coined the underlying problem, that which fed social disconnection (Adler 1938). These cognitions of inferiority fuel what he coined the "superiority complex;" attitudes and fantasies of greatness which serve to defend against any feelings of inferiority, but instead, often contribute to a flight from reality, and ultimately, a deviation from society (Adler 1938). Unstable attachment relationships coupled with chronic frustrating and depriving experiences can result in the increased stimulation of aggression which "very quickly determines the whole inner development and creates, according to Adler, 'a superior mental field' which prevails over the developing inner world" (Lang 2009, p. 98). Clinically, we see these complexes playing out in personality disorders with their common primitive defense of splitting. Clinically, they present as oscillating between selfhate and grandiosity. According to Adler, the two complexes are really just two sides of the same coin. The rhetoric and bullying that is becoming so mainstream in today's society is an example of the inferiority and superiority complex's destructive path. Social workers should be trained to look for and help correct such feelings of inferiority.

Individual Psychology looks at the cognitive assumptions that help guide, understand, predict, and attempt to control an individual's experience (Lantz 1980). If these cognitions are false, they would feed the person's life plan and feelings of inferiority. Adler used the terms life style, life goal, fictional goal, and guiding fiction interchangeably to describe that which a person uses to overcome inferiority feelings. This life style or goal is made up of cognitive assumptions. Every action and feeling, conscious and unconscious are driven by the perception of a goal (Adler 1923). Adler sees the development of character as reflecting this early-established goal; he described character traits as tricks that the personality used to acquire recognition (Adler 1927). He felt education required assessing any faulty information the child may be employing, helping them to see their mistakes and ultimately, increasing their cooperation and interest in other people. Adler believed that birth order, family constellations, life tasks and community feeling were to be used as assessment tools for an individual, couple or family's social embeddness which fueled a person's goal. Balla (2019) describes the idea of social embeddness, as a basic tenet of Individual Psychology, and described it as a foundation for both systemic thought and social learning as well critical to the development of one's life narrative. Community feeling is a deep sense of connectedness to others and being a part of the human community whereas social interest is considered by Sommers-Flanagan and Sommers-Flanagan (2012) "community feeling in action" (p. 84). Watts (2000, as cited in Sommers-Flanagan and Sommers-Flanagan 2012) contends, "The ultimate goal for psychotherapy is the development or enhancement of the client's social interest. As an individual's social interest develops, so does the capacity for empathy and altruism" (p. 84).

Adler (1938) espoused that children are excellent observers, but also says they are terrible interpreters; therefore, they develop a life style around faulty information. Consequently, children set up concrete goals that go against their own welfare and the development of humanity. A technique Adler used to determine a client's life plan or guiding fiction was asking about a first memory, as well as a recent life event; in this way he would be able to see the continuous thread of the lifelong goal (Adler 1927; Ellenberger 1970).

An adult's first memory is of finding a tricycle hidden in the bathtub, and the excitement he felt. Within a day or so, the child's father died of a heart attack while he was present. This tragedy happened a day before the child's birthday. On 
some level, the child felt that his finding this hidden tricycle, a birthday surprise, and his excitement, caused his father to die. He experiences extreme guilt, and as an adult, he is always depressed around the time of his birthday. Consequently he has built his life around not owning things and has tried to avoid getting too excited about anything, believing on some level that ownership and excitement will result in loss and even catastrophe. He sublimated his feelings of inferiority, and threw himself into a respectable but hated career where he often makes a good living, but never invests in anything that will bring him too much joy. ${ }^{1}$ Adler contended, "As grown-ups, we are still making the use of prejudices and fallacies of our childhood as though they were sacred laws" (Adler 1927, p. 166). Adler saw the child as developing these often-faulty ideas by age four or five and called this a "prototype" for future development. He believed future thinking shapes behavior (Corey 2017).

Another Adlerian tool is asking a client to write a future autobiography. This exercise is helpful in both the assessment process as well as a therapeutic technique. It can help identify a person's fictional goal and whether this ideal is helping or hindering the person's functioning. Therapeutically, it can be used to help a person create new images for their life, images that are more realistic and adaptive (Sommers-Flanagan and Sommers-Flanagan 2012). This process can be lengthy and rewritten throughout the therapy. An example of this intervention follows: "Write the rest of your story from here on out. And as you do, keep this in mind: Write a story in which you are not perfect, one in which you make mistakes, but overall, live in an acceptable and loving way in the world" (Sommers-Flanagan and Sommers-Flanagan 2012, p. 101). Bankart (1997) sees the future autobiography operating much like dream analysis as they are both used to uncover the life goal.

As with contemporary cognitive behavioral therapythough in a different language-the uncovering, re-evaluating, and correcting of cognitive distortions is central to the Adlerian approach. This is why he felt that education was so critical, and why he trained teachers to assess and properly educate children at risk. He considered the first 5 years to be the most important in terms of proper learning and developing a healthy life goal (contributing to society rather than being superior and disconnected) but acknowledged that by the time children go to school, this prototype is already developed. He believed that the proper education of children is critical and that the mother played the most important role in the education and encouragement of the child and that the child's sense of social connectedness could be glimpsed from just a few weeks old. Adler said, "We probably owe to the maternal sense of contact the largest part of human social feeling, and along with it the continuance of civilization"

\footnotetext{
${ }^{1}$ Client consent obtained
}

(1938, p. 221). He believed it was the therapist, teacher or child guidance counselor's role to provide education if the mother had fallen short. In the above case, it is possible that the mother was so grief stricken that she was not able to comfort her son appropriately, or even realize that her son felt he was at fault, and was in no position to correct the faulty cognition.

These days, we would substitute "caregiver" for "mother." While many of Adler's ideas were progressive for his time, some of his ideas and terminology have not dated well. For instance, one example he gives of organ inferiority is lefthandedness. These days left-handedness is considered fully acceptable; this author is left handed, and has never been made to live any other way. But her left-handed father was forced to write with his right hand, a socially accepted practice at the time. Likewise, homosexuality was seen by Adler as a lack of social interest and an actual choice, however, modern day Adlerians address this shortcoming in their writings (Brown et al. 2020). They do not see homosexuality as either a choice or something that needs to be fixed. Individual Psychology strives for social adjustment, and I imagine if Adler were still alive today, his views would have adjusted to the new understanding of the times.

To address the shortcomings of caregivers, Adler and his associates established 28 child guidance clinics by 1930 (Adler and Associates 2013/1930). These centers worked with parents, teachers, doctors, and social workers on how to impart proper education to children so that they could become secure and sufficiently connected to society. Adler saw proper child guidance and education as the lynchpin of prevention; he stressed the need for the communal participation of the family, teachers, and other helpers to be indispensable (Adler 1938).

The following description is a historical illustration of the communal outreach that Individual Psychology used to spread its message:

The district parents' association of the twentieth Vienna city district, for instance, has organized this year for the second time a parent's guidance school where for six or seven evenings an introduction is given to Individual Psychology. Of the twenty-seven schools and five kindergartens of the district the course is frequented on the average by three or four parent's councils, and this means an average attendance of ninety persons. In this way there is no school in the district in which at least some of the parents have not been initiated into the ideas of Individual Psychology. And these parents often induce us to give in their schools, for the benefit of all parents, lectures on educational problems from the point of view of Individual Psychology. This naturally results in a higher attendance at the guidance clinic maintained by the district 
parents' association. The work of the organization and enlightenment carried out by our teachers assumed such dimensions last year that for weeks the guidance clinic was compelled, owing to its excessive attendance, to open an annex (Zerner 2013/1930, p. 87).

Pedagogy was of great importance and the clinics taught parents to foster sociability in the child, never to beat or degrade a child, not to pamper or keep them in a state of dependence, to offer chances for reconciliation and making amends, and at times, even to overlook mistakes or acts of defiance (Freidman 1930). Adler and Associates (2013/1930) identified four steps integral in successfully educating the family. The first, of course, is building trust in those seeking guidance. After this has been established, it is imperative to locate any sources of educational errors; the final two steps are encouragement and stimulating social sentiment. Tragically, at the peak of their popularity, these child guidance centers were closed down by the Nazi regime.

In Adlerian psychology, encouragement of the child is key to bringing about positive change. Adler's own daughter, who followed in his professional footsteps, gave the following description of a technique used with a child who was doing poorly in the area of writing. Adler (2013a/1930) explained:

We have won our game if we have succeeded in encouraging the child in some way or other. To be sure our starting point cannot be arbitrary. We must begin at the source of his errors. Since we aim above all to stimulate self-confidence and self-respect, we gladly attach ourselves to some positive achievement of the child. Thus we ask a backward child who likes to draw to bring us a drawing the next time. We are always astonished to see how gladly and punctually the children fulfill their task, how much joy our interest gives them, and how proud they are of our praise. After he has shown us the drawing, we tell him that he certainly could write equally well if he were willing to practice in writing as much as in drawing. We later have him bring some of his written work, pointing out to him even the smallest progress made (p. 115).

The child in the example above may have believed they could not write well, and this feeling of inferiority in writing, without intervention, may have led the child to lose courage and give up not only on writing, but perhaps in other areas of life as well. Adler (2013a/1930) would say to a child, "because you have difficulties with your school work, you believe that you cannot succeed in anything and you give up the race" (p. 114). She explicitly pointed out the child's faulty cognition. Working with parents and teachers was also key to the child's success. Individual Psychology explicitly guided parents on how to intervene to adjust their child's faulty ideas. The following is an actual intervention suggested by Alfred Adler (as cited in Seidler 2013/1930) for a young girl who was acting out. He believed the child's acting out was because she felt the mother preferred her siblings.

Whenever she feels that she is menaced she fights, whenever she feels certain she is calm and does good work. I would advise you to go away for a few days with Frieda, but with Frieda alone, if this is possible for you. Then explain to her during a walk that you like her as much as her sisters, that the sisters, however, need more attention since they are small; tell her also that you are very proud of your big daughter who is such a proficient pupil. I believe that Frieda will give up her combativeness if you talk to her in such a spirit (p. 187).

Ellenberger (1970) describes Individual Psychology as proceeding in three phases. The first phase is engagement with, and assessment of, a client's life plan. The second phase is meant to expose a client or client's parent to their secret lifegoal as is shown in the above examples. In the third phase, the client decides whether they want to change their goal, and if affirmative, work is done toward this end. Individual Psychology has been criticized for its lack of defined technique. This is because the treatment philosophy is actually what drives Adlerian technique (Lantz 1980). Individual Psychology methods should look at the whole of a person's personality, identifying and weighing their goal of superiority, along with the strength of their feeling of inferiority and how these directly influence their degree of social feeling and adjustment to society (Adler 1938). Social workers should incorporate these methods into the assessment process.

Despite his emphasis on individual difference, Adler used a generalized guiding principle of "half and half" to describe each person's shared responsibility with their environment for their particular circumstances. "We should not depreciate either ourselves or our environment; but, assuming that each is one-half in the right, affirm the reality of ourselves and others equally (...) The individual should affirm his part in everything which occurs to him, as his own half of it" (Adler 2013b/1930, p. 22). People often see things as happening to them, rather than feeling their responsibility in the occurrences of life. Individual Psychology compassionately helps them to see their part. If the social work profession consistently employed Adler's metaphor of "half and half" in clinical nomenclature, eventually the idea might become normalized and asking a person what their half of the equation is might feel less threatening. Perhaps accountability, seen lacking during Covid-19 and the controversy around wearing masks, might become more commonplace. 
In keeping with his belief in accountability, Adler felt actions were more important than words, and that good therapeutic technique carefully follows a person's actions, as if the therapist were watching "a pantomime" (Adler 1964, p. 18). After observing a person in this way, the next step of Adlerian technique is to show a patient his faulty, and often unconscious, life plan, so that the client can take the action needed to interact fruitfully with society and its demands (Adler 1923). This can be seen in the following explanation by Adler (2013b/1930):

We must decrease his feelings of inferiority by showing him that he really undervalues himself. We can show him the trouble with his movements and explain to him his tendency to be over tense, as if standing before a great abyss or as if living in an enemy country and always in danger. We can indicate to him how his fear that others may be preferred, is standing in the way of doing his best work and making the best spontaneous impression" (p. 112).

Stein (2014) writes that to uncover the client's guiding fiction, the clinician needs to learn how to interpret a client's physical movements in terms of their psychological significance, something that Adler emphasized repeatedly. Stein admits this is a skill missing from most Adlerian training today. Individual Psychology can gain insight from psychoanalytic defense analysis, which both notices and interprets movements, often seen as defenses.

To encourage action, rather than being satisfied with words or insights alone, Adlerians explicitly employ the technique of encouragement. According to Watts and Pietrzak (2000), Adlerian methods of encouragement seek to help clients identify and combat discouraging and false cognitions, create perceptual alternatives, and focus on noticing their own actual efforts as well as all their resources and strengths. Dream analysis is used to uncover the client's unconscious life plan and self-deception (Adler 1927; Ellenberger 1970). Another technique to ask, "Supposing that you did not have this ailment, what would you do?" Adler believed the patient's answer to this question indicated exactly what they wanted to avoid (Ellenberger 1970, p. 620). Adler underscored the need for encouragement because he believed that only with a trusting and positive therapeutic relationship could client learning take place. This viewpoint led him to reject use of the couch as part of the therapeutic frame; he felt that the therapist and client should sit face to face, undermining any power differential. In this same vein, he did not use hypnosis, as he felt it to be degrading for both the client and analyst (Ellenberger 1970). Writing about Adler's Individual Psychology, Bankart (1997) says,
The goal is to teach the person about the potential emotional and psychological rewards that come with awakening the social-interest motive. The patient generally needs to abandon a neurotic fixation, a complex of self-protective strategies that have been in place since early childhood. This task requires the patient to have an enormous amount of trust in both the therapist and the world (p. 145).

Adler's psychology has been criticized for being too pedestrian (Sommers-Flanagan and Sommers-Flanagan 2012). Adler used language that all people, not just trained analysts, could understand. While it might not possess the cache of psychoanalysis, Adler's jargon-free language seems to this author, who is psychoanalytically trained, to have immediate clinical value. Adler saw shame as a consequence of the experience of inferiority (Ansbacher and Ansbacher 1956); important to his psychology was that such feelings be normalized and labeled as part of the human condition. A client who has such feelings named and normalized feels less like an outsider, and their feelings of inferiority lessen as a result. Over the years the author has given many psychoanalytic interpretations; however, the intervention that has seemed most consistently to bring relief of shame is surprisingly straightforward in its Adlerian simplicity. When someone is expressing shame for the intensity of their feelings, which is known to be triggered by earlier experiences, I will offer a variant of the following: "It makes sense to me why you would be feeling this way. Feelings don't grow up. They are as important now as they were when you first felt them." This intervention speaks to the power and universality of feelings, helping to reassure the client that their emotional responses are normal, even a sign of their basic humanity.

Many clients are riddled with self-loathing when they perceive they have not lived up to a version of western philosophy that extols independence. As such, they feel immense shame in asking for help. Adler's theory sets this underlying standard of behavior on its head by underscoring how much we are interdependent. Shame in asking for help can be empathically engaged and social workers can educate their clients about the importance of interdependence and mutual connection. This interdependence is amply supported by both attachment theory and neuroscience (Bowlby 1969; Karen 1998).

\section{Adler's Influence on Social Work Practice}

As Ellenberger (1970) states, it is difficult to accurately trace Adler's influence on current psychology; it seems equally difficult to assess Adler's influence on the field of social work. While Individual Psychology is highly compatible with the principles of social work and many of Adler's ideas 
are implicit in social work practice, and although social workers even staffed his child guidance centers (Adler and Associates 2013/1930), the field seems strangely removed from his body of work in the sense that his contributions are rarely mentioned and little known. Adler's idea of social embeddedness long preceded McGoldrick's common social work tools of investigation like the genogram or family life cycles and gender and cultural grounding (Balla 2019). This author argues it is time to revisit his original ideas so that new tools can be cultivated. To begin this process, the author conducted a literature search. Not surprisingly, the majority of literature found is from the Journal of Individual Psychology. The most current finding (2020) highlights the overlapping concepts shared by Adlerian family therapy and the family systems theory of social interest, holism and belongingness. The case of a transgender couple who is planning on having children is examined using these principles (Brown et al. 2020). The article also addresses Adler's outdated understanding of homosexuality as a choice and how modern Adlerian psychology practices have redressed this.

Adlerian Play Therapy (AdPT), developed by Kottman in the 1980s and based on Adlerian principles, has reached evidence-based treatment status (Meany-Walen 2020). A randomized control trial by Meany-Whalen et al. (2014) investigating the efficacy of AdPT on elementary school children was robust enough that it was adopted by the Substance Abuse and Mental Health Services Administration. They found AdPT to be a promising intervention for reducing disruptive behavior in the classroom, improving children's on-task behaviors, and reducing teacher stress. AdPT therapists use a specific Adlerian treatment protocol detailed in the Treatment Manual for Adlerian Play Therapy. This manual was developed in 2009 but is continuously under revision to ensure the fidelity of treatment (Meany-Walen 2020).

La Guarda and Banner (2012) highlight the importance of the Adlerian family reunification model that is being employed in the foster care system. When reunification is the goal, interventions are targeted at both the family of origin and the foster family. The authors encourage workers to develop ways to involve members of the family of origin in treatment throughout the child's placement in foster care. Children should also feel that they have a say in what happens to them. Parent training, family counseling, and community-based open forum interventions are needed if the goal is reunification of the family. Using a strengths-based perspective, this model helps children and families to learn useful communication skills, recognizes maladaptive interactional patterns and reeducates to address them, and teaches mutual family respect and attaining democratic family solutions that do not create discouragement. This model also calls for an active recognition of cultural, socioeconomic, and mental health needs to determine appropriate treatment plans. This model combats pathologizing clients and families, something unfortunately inherent in many current social welfare policies. Edwards (2007) argues that maintaining consistent parental involvement throughout the entire process could help decrease the time a child is away from home by up to a year (La Guarda and Banner 2012, p. 364).

In 2005, Farooq et al. realized that contemporary challenges were causing parents to seek new knowledge around how to effectively parent, as they recognized the inadequacy of old paradigms. Noticing a lack of parenting programs available to minority populations, Farooq et al. created a study to gauge the effectiveness of an Adlerian video-based parent education program. Forty African-American innercity parents raising children from ages eleven to eighteen participated and were assigned randomly to either a training or a control group. Results showed those taking the Adlerian training had more empathic perceptions of their children's behavior and proved effective at also generating more authoritative (rather than authoritarian or submissive) parenting styles.

Adler is hardly mentioned in casework literature, even though caseworkers' practice principles are often highly aligned with the Adlerian approach (Lantz 1980). O'Connor (1992) highlights a case in which a resistant patient in a hospital setting finally responds to Adlerian approaches: "As an Adlerian, I believe that resistance is a manifestation of the client and the counselor having different goals" (p. 121). O'Connor undoes the resistance by aligning herself with the patient's stated goals, and helps the patient to see she has a choice in being depressed or not depressed, encouraging her to look at the positives in her life. The ultimately successful placement of this patient in a therapeutic community demonstrates the importance of Adler's principle of social feeling; this patient could now meet the needs of work and friendship, fostering her sense of belonging. This example highlights the need for a proper discharge plan, something social workers normally assume the responsibility for. A hospital social worker might ask in an Adlerian way, "What is the best way to help the patient meet his or her life tasks?".

Adler looked at family as critical in shaping individuals and their life goals. Fashimpar (2000) tests an Adlerian parenting training program, as parenting training is often mandated by child protective services and juvenile courts, or recommended by family service agencies, private practitioners, or school social workers. Fashimpar contends that the lack of social work literature on parenting training creates deficits in appropriate replication of successful interventions, and creates this study to bridge this gap; the goal is to measure and evaluate the Adlerian parenting training. The goals of this specific Adlerian Parent Training (APT) are to alter communication patterns, democratize family roles, and increase respect among family members. The outcome 
of this study showed a decrease in serious parent-child relationship problems, specifically a reduction in corporal punishment. It also showed that it might be ineffective in changing empathy, developmental expectations, or family roles. A limitation to this study was its small sample size, $\mathrm{n}=35$. More Adlerian studies are needed.

Yura (1983) writes from an Adlerian perspective on how best to raise a child with special needs. This parenting topic is specifically poignant in its relation to Adler's concept on organ inferiority. Adler believed that the parents of special needs children were responsible for appropriately educating the child, and that any mistaken life view developed by the child was the parent's responsibility and could not be attributed to the child's disability. He felt with the proper training and guidance, the disability could be turned into an asset by stimulating the child to overcome obstacles and move toward even greater achievement (Yura 1983). Adler warned against special needs children being pampered or in any way discouraged from achieving, since this fosters their belief that they cannot achieve. Parents must also recognize and correct purposeful behaviors that are not leading the child to secure a place of belonging in the world. Adler also espoused using logical consequences, believing they teach the relationship between behaviors and their consequences. He held that teaching their children to successfully cope with life's tasks is especially critical for parents of special needs children. Adler's philosophy and techniques can help parents to feel more prepared to take on the oftentimes overwhelming task of caring for children with special needs (Yura 1983).

\section{Adler's Compatibility with Contemporary Social Work}

Watts (2000) links Adlerian theory with current postmodern approaches taught in social work; specifically, constructivist therapy, solution-focused therapy, and narrative therapy. All of these theories elevate clients as capable collaborators with the therapist, and are all strength-based in their approaches (Reid 2002). Adler (1923) felt it was crucial to be able to attribute the work and success of the cure to the client. Relational-cultural theory elaborated by Jordan (2010) asks us to look beyond the individual and identify disempowerment and disconnection in the larger culture; in this way, it tracks exactly with Adler's thought. (This conceptual framework, we might note, is currently reflected in the Black Lives Matter movement). Finding the degree of an individual's capacity for cooperation in society is paramount to Adler's Individual Psychology and the goal that drives all of its interventions.

Adler has often been mislabeled a Neo-Freudian; this may be in part because the Neo-Freudians closely resemble Adler. For this reason, Wittels (1939) coined the term
Neo-Adlerians. The interpersonal school including Fromm, Horney, and Sullivan have much in common with Adler and were likely influenced by him. All participated in the rising awareness of societal influences on individual development that arose in Germany during the inter-war years. Horney's own writings have much in common with Adler's, specifically her focus on culture and feminism. According to Paris (1994), Horney was strongly influenced by Adler's ideas about how individuals compensate for feelings of inferiority, particularly his concept of "masculine protest," or the internalization of a masculine ideal, in which she admitted recognizing herself. It is curious, to say the least, that although so many current theories draw from Adler's ideas, he is hardly mentioned. One possible explanation is offered by Watts and Pietrzak (2000): "Adler's ideas were marginalized because they were out of step with the dominant metaphors at the time, and consequently, his theory was discounted, even though many of his ideas have been assimilated into subsequent theoretical positions" (p. 445). According to D. Ingram, "the dominant metaphors shifted and centered around autocratic power. Integrated into psychoanalytic theory, the notion of the 'harsh superego' or, for Horney, the 'tyranny of the shoulds.' As that historical era closed with the passing of powerful autocratic leaders, an inclination in the West towards egalitarianism evolved" (personal communication, August 11, 2020).

Adler's work reinforces two important components of the contemporary social work curriculum, attachment theory and object relations theory, while lending an important, often missing, historical lens. In 1939, Wittels wrote, "Adler pointed out how secure and cheerful we feel when a part of the group in which we move and how we become victims of anxiety and inferiority when alone with ourselves-whence the flight into mental or nervous disease" (p. 236).

Of John Bowlby, the founder of attachment theory, Karen (1998) says, "He shows an unusual concern with matters outside the realm of psychiatry - in particular with social concerns and social policy" (p. 57). This "unusual concern" was shared by Alfred Adler. In fact, Adler's concept of a guiding principle has much in common with the internal working models described in attachment theory. The guiding principle is formed by the end of infancy and corresponds to preverbal representations and structures described by attachment research (Lang 2009; Sommers-Flanagan and Sommers-Flanagan 2012). Lang (2009) contends that patients who are suffering from a developmental history of insecure attachment relations and early physical deficiencies are more likely to develop the feelings of inferiority described by Adler. Notwithstanding such histories, Lang believes Individual Psychology offers a way to help patients unlock creative forces to change their fixed personality structure, and that successful therapy will help the patient change the conscious and unconscious opinions that he holds 
towards himself and others hold towards him. Adler's focus on aggression offers a distinct lens into the psyche of traumatized individuals who suffer from personality disorders: "The neurosis is a self-torturing device for the purpose of enhancing the self and depreciating the environment. And indeed the first stirrings of the aggression drive against one's person originate from a situation in which the child wants to hurt the parents or wants to attract attention more effectively" (as cited in Ansbacher and Ansbacher 1956, p. 271).

Attachment theory and object relations theory are neatly aligned. Karen (1998) posits that the Bowlby's thinking was most compatible with, and likely influenced by, Ronald Fairbairn. Adler's aforementioned guiding principle in fact preceded Fairbairn's object relations theory. Mitchell (1998) wrote, "It was Fairbairn's most far-reaching contribution to be among the first to intuit that the establishment and maintenance of relationships with others is as fundamental to the nature of the human organism as oxygen-breathing" (p. 118). Decades prior to Fairbairn's contributions to object relations theory, Adler (1927) said, "One can always observe that the child directs his effort for affection toward others, not towards himself, as Freud believes" (p. 32). Adler's aforementioned concepts of community feeling and social interest embrace human relations and drive Adlerian psychology. Research has supported the idea that social interest is positively related to human attachment (Sommers-Flanagan and Sommers-Flanagan 2012).

Adler, like Fairbairn, felt that major psychological organization begins with the first frustrations in infancy. Fairbairn said that all infants, when they feel frustration, experience "a sense of a lack of love, and indeed emotional rejection on [their mothers'] part" (Fairbairn, 1952, p. 112). Lang (2009) writes, "most important is the subjective experience of the baby, namely - according to A. Adler - the lack of satisfaction of his "need for tenderness"' (p. 98). Fairbairn's endopsychic structure also has much in common with Adler's idea of a guiding principle. The endopsychic structure is an unconscious inner world consisting of objects, or internalized relationships, both good and bad, that the developing ego creates as a defensive maneuver to control rejecting external objects. This internal structure deeply influences a person's life experience, especially their perceptions of the outside world and the ways they respond to it (Grotstein and Rinsley 1994). Adler's guiding principle also consists of inner structures that contain unconscious opinions of self and others, these inner structures are both active and goal directed (Lang 2009). Adler's emphasis on asking about a first memory can illuminate some of the content of these inner structures and help uncover a person's style of life. Both Adler and Fairbairn agree that mental health is dependent on integrating new ideas and healthier objects into the person's psyche. If Adler were alive today and familiar with contemporary theories, he might integrate cognitive and psychodynamic work, saying something akin to: Our inner objects or internal working models guide our behavior, and if we are able to recognize and change our perceptions of our inner objects, we can change both our behavior and our faulty style of life, and in turn, become more fulfilled and connected to society.

In addition to the aforementioned contemporary social work theories, Adler can be linked to and enhance social learning theory and systems theory (Balla 2019). Adler's work complements course work already taught in MSW programs, specifically, Human Behavior in the Social Environment courses. Lev Vygotsky's Sociocultural Theory of Cognitive Development posits development is optimal when the child can interact with those who are more experienced and competent. He believes these interactions create a "zone of proximal development" where they can function at a higher level than they could on their own, and eventually they will internalize these new forms of thinking and expertise (Haight and Taylor 2013). Social workers also learn about Urie Bronfenbrenner's Developmental Ecological Systems Framework that describes how interacting embedded systems, which he likens to Russian nesting dolls and calls micro, meso, exo, macro and chrono systems, impact human development over the lifespan. Bronfenbrenner (1990) saw human development as taking place principally in the mind, and held that while people, objects and symbols initially exist in the environment, they become internalized; during this process they are also transformed. Adler's Individual Psychology would be focused on this point of transformation, aiming to identify and correct any faulty educational errors while simultaneously encouraging the individual and stimulating social sentiments. The very social nature of Adler's guidance centers also supports the "zone of proximal development":

The work in our child guidance clinics proceeds in most cases with the doors wide open. The public character of these clinics has often been attacked. Our experience has shown, however, that the appearance of the child before a large gathering-that is to say, the public character of the guidance- has a stimulating effect upon him. The publicity of the procedure suggests to the child that his trouble is not a private affair, since strangers are also interested in it. His social-mindedness is more awakened through this (Seidler and Zilah 2013/1930, p. 23).

Adler's child guidance centers, while providing a rich historical example for the social work profession and an example of the chronosystem, could also be used to illustrate the other four ecological systems. Bronfenbrenner also stresses reciprocity between systems, which Adler's ideas highlight. 


\section{Conclusion: Why Include Alfred Adler in Social Work Curricula?}

Kenneth Clark, the first African American president of the American Psychological Association, studied Adler's psychological principles and provided persuasive notes on them that greatly influenced arguments made before the Supreme Court against the "separate but equal" doctrine of Plessy v. Ferguson (1896) (Griffith and Powers 1984). According to the lead lawyer in Brown v. Board of Education of Topeka Kansas, Thurgood Marshall (who later became the first African-American Chief Justice), Chief Justice Earl Warren said that Clark's testimony, which relied on an understanding of Adler, was instrumental in overturning Plessy v. Ferguson (Griffith and Powers 1984).

Individual Psychology considers social equality fundamental, and argues that it needs to be explicitly taught. By means of the therapy of encouragement, Individual Psychology helps free people from neurotic self-interest and show them the true worth of their contributions to society (Adler 2013b/1930). Thus, in Adler's conceptualization, the psyche's well-being is inseparable from that of the larger society, and connection between society's members is always preferable to separation. Clark used Adler's idea of the "inferiority complex" to show how segregation fueled feelings of inferiority (Griffith and Powers 1984) and ultimately divided people.

Almost a century ago, Seidler and Zilah (2013/1930) recognized the importance of Individual Psychology on various systems and predicted, "More and more will the necessity be felt for applying Individual Psychology to the training of parents, vocational educators, teachers, officials, judges; in short, of all those who have to deal with children and education (p. 27). Current challenges related to the pandemic have created an educational crisis demonstrated by an increase in failing grades, lower attendance in school and an increase in social inequalities (Kuntz 2020). Given the findings of the Farooq et al. (2005) study, in which an Adlerian video-based parenting education program showed excellent results, social workers familiar with Adler's work might consider revitalizing some kind of virtual modern-day child guidance centers. This intervention would be timely, and likely welcomed, as parents have no choice but to assume a much more integral role in their children's often online education. The following quote by Spiel and Birnbaum (2013/1930), is especially relevant at this time:

Our guidance clinics in this way have become something more than guidance centers; they have become transformation centers and driving powers. Like all driving powers, they lead more and more to new forms of organization. The wide chasm between home educa- tion and education in educational institutions must be bridged by intermediary institutions (p. 83).

Social workers knowledgeable in Individual Psychology would be well equipped to act with teachers as such intermediaries. Utilizing the latest technologies and Adlerian principles, an important goal would be to make parents allies by helping them to help their children be courageous and independent (Adler and Associates 2013/1930) navigating online learning in a very stressful time.

This author proposes that Alfred Adler be added to all social work curricula and taught along with Freud. Professionals trained in the School of Individual Psychology could be hired to lecture on Adler in our social work schools. Adler's focus on prevention is a cornerstone of his theory; social workers are often on the front lines of child abuse protection and prevention, including in schools, the place Adler felt could offer the best prevention of societal ills. "Adler's Individual Psychology is taking a renewed interest in the ways in which laws, public policies, institutional behaviors and popularly-held attitudes can lead to such social problems as poverty, homelessness, hunger, illiteracy, sickness and judicial inequity" (Todman and Mansager 2011, p. 92). The aforementioned Supreme Court Case ruling is just one-albeit monumental-demonstration of how effectively Adler's work can cut to the heart of our society's deepest ills. In Adler's words, "What we call just and righteousness, and consider most valuable in the human character, is essentially nothing more than the fulfillment of the conditions which arise in the social needs of mankind" (Adler 1927, p. 32).

Perhaps if more social workers were familiar with the "pioneer of prevention" (Ansbacher 1992), research efforts and grant writing might be galvanized to more successfully obtain much-needed mental health prevention funding. If Adler's psychology was persuasive enough for the Supreme Court on issues of social injustice in 1954, it is likely to be at least as persuasive now. As we struggle through a pandemic, it is worth reiterating that Adler's first published ideas were in the field of social medicine and that he believed much of disease to be a product of society (Ellenberger 1970). All of Adler's writings indicate he saw social interest as a solution. Adler's life work and its application to both the micro and macro systems can help bridge the split that has always divided the social work profession into an either/or debate over treating the individual vs. society. Adler spent his career compassionately treating clients, educating the public, and creating programs that treated individuals and families while also creating a psychology that explicitly valued social justice, and was robust enough for Albert Ellis to deem Adler "The true father of modern psychotherapy" (as cited in Sommers-Flanagan and Sommers-Flanagan 2012, p. 115). Who better to embrace Adler's ideas than the social work profession, and what better time? 
This author believes that educating social workers about Alfred Adler will do much to revitalize his important contributions; reciprocally, his contributions will add value to the social work profession. Posthumously, Adler seems to struggle from an identity crisis parallel to the one that the social work profession often faces, both at least partly based on a false dichotomy between the individual and society. The inseparability of the two represents the greatest and most unavoidable argument for equality. Sadly, one might wonder if Adler's campaign for women's and minorities' equality may have contributed to his voice having been forgotten. Yet as voices for equality get louder, Adler's voice is one we might listen for across the years. One can imagine if he were still alive, he would kindly remind us all, "The fundamental law of life (...) is that of overcoming" (Adler 1938, p. 7).

\section{References}

Adler, A. (1923). The practice and theory of individual psychology (Radin, P., Trans). New York: Routledge \& Kegan Paul LTD.

Adler, A. (1927). Understanding human nature (Wolfe, W. B., Trans.). New York: Greenberg Publisher.

Adler, A. (1938). Social interest: A challenge to mankind (Linton, J., Vaughan, R. Trans.). London: Faber and Faber, 1td.

Adler, A. (1964). Individual psychology of Alfred Adler: A systematic presentation in selections from his writings (Ansbacher, H. L., \& Ansbacher, R. R., Trans.). New York: Harper and Row Publishers.

Adler, A. (1982). Co-operation between the sexes: Writings on women and men, love and marriage, and sexuality (Ansbacher, H.L., \& Ansbacher, R.R., Trans.). New York: W.W. Norton \& Company

Adler, A. (2013a). Technique of educational guidance. In A. Adler et al. (Eds.), Guiding the child (psychology revivals): On the principles of individual psychology (1st ed., pp. 102-108). Routledge. (Original work published in 1930).

Adler, A. (2013b). The science of living (psychology revivals) (1st ed.). Routledge. (Original work published in 1930).

Adler, A. (2013c). A case from child guidance. In A. Adler et al. (Eds.), Guiding the child (psychology revivals): On the principles of individual psychology (1st ed., pp. 127-147). Routledge. (Original work published in 1930).

Adler, A., \& Associates. (2013). Guiding the Child (Psychology Revivals): On the Principles of Individual Psychology (1st ed.). Routledge. (Original work published in 1930).

Ansbacher, H. L. (1992). Alfred Adler, pioneer in prevention of mental disorders. Individual Psychology: The Adlerian Journal of Research, Theory, \& Practice, 48(1), 3-34.

Ansbacher, H., \& Ansbacher, R. (1956). The individual psychology of Alfred Adler: A systematic presentation in selections from his writings harper torchbooks. New York: The Academy Library Harper \& Row, Publishers.

Balla, M. (2019). A case study of social embeddness and social responsibility. The Journal of Individual Psychology, 75(4), 259-271.

Bankart, C. P. (1997). Talking cures: A history of western and eastern psychotherapies. Pacific Grove: Brooks Cole Publishing Company.

Borenzweig, H. (1971). Social work and psychoanalytic theory: A historical analysis. Social Work, 16(1), 7-16.

Bowlby, J. (1969). Attachment and loss, volume one: Attachment. New York: Basic Books.
Bronfenbrenner, U. (1990). The developing ecology of human development: Paradigm lost or paradigm regained. Berkeley: University of California.

Brown, K., Londergan, K., \& Bluvshtein, M. (2020). And they lived happily ever after: An intimate closeness of systems and adlerian theories in the case of a transgender couple. The Journal of Individual Psychology, 76(1), 128-140.

Corey, G. (2017). Theory and practice of counseling and psychotherapy. Boston: Cengane Learning.

Cushman, P. (1995). Constructing the self, constructing America: A cultural history of psychotherapy. New York: De Capo Press.

Ellenberger, H. F. (1970). The discovery of the unconscious: The history and evolution of dynamic psychiatry. New York: Basic Books.

Fairbairn, R. W. (1952). Endopsychic structure considered in terms of object relationships. Psychoanalytic Studies of the Personality (pp. 82-132). London: Routledge and Kegan Paul.

Farooq, D., Jefferson, J., \& Fleming, J. (2005). The Effect of an adlerian video-based parent education program on parent's perception of children's behavior: A study of African American Parents. Journal of Professional Counseling: Practice, Theory, \& Research, 33(1), 21-34.

Fashimpar, G. (2000). Problems of parenting: Solutions of science. Journal of Family Social Work, 5(2), 67-79.

Freidman, F. (1930). Escape to disease. Adler, A. \& Associates. Guiding the Child: On Principles of Individual Psychology (pp. 53-65). (Ginzburg, B. Trans.). New York: Greenburg Publisher.

Griffith, J., \& Powers, R. (1984). An Adlerian Lexicon: Fifty-Nine terms associated with the individual psychology of Alfred Adler. Chicago, IL: The American Institute of Adlerian Studies.

Grotstein, J., \& Rinsley, D. (1994). Fairbairn and the origin of object relations. London: Free Association Press.

Haight, W. L., \& Taylor, E. H. (2013). Human behavior for social work practice: A developmental, ecological framework. Chicago, IL: Lyceum Books.

Hirsch, P. (2005). Apostle of freedom: Alfred Adler and his British disciples. History of Education, 34(5), 473-481.

Hoffman, E. (1994). The drive for self: Alfred Adler and the founding of individual psychology. Boston: Addison Wesley Publishing Company.

Ingram, D. (personal communication, August 11, 2020)

Jordan, J. (2010). Relational-cultural therapy. Washington, DC: American Psychological Association.

Karen, R. (1998). Becoming attached: First relationships and how they shape our capacity to love. New York: Oxford University Press.

Kuntz, C. (2020). My Champlain Valley [Television Series] [Television Series]. Burlington, VT: NBC.

La Guarda, A., \& Banner, A. (2012). The goal of reunification: An Adlerian approach to working for therapeutic change within the foster care system. The Family Journal: Counseling and Therapy for Couples and Families, 20(4), 361-368.

Lang, H. J. (2009). Anger, aggression and hate: Concepts influenced by infant research and attachment theory-an individual psychological perspective. Psichologija: Praktika, 39, 93-108.

Lantz, J. (1980). Adlerian concepts: A caseworker's review. Clinical Social Work Journal, 8(3), 191-197.

Makari, G. (2008). Revolution of the mind: The creation of psychoanalysis. New York: Harper Collins.

Meany-Walen, K. (2020). The current state of adlerian play therapy published research. The Journal of Individual Psychology, 76(2), 176-186.

Meany-Whalen, K. K., Bratton, S. C., \& Kottman, T. (2014). Effects of adlerian play therapy on reducing students' disruptive behaviors. Journal of Counseling and Development, 92, 47-56. 
Miller, J. B. (Ed.). (1973). Psychoanalysis and Women: Eminent psychoanalysts dispel myths and explore realities. London: Penguin Books.

Mitchell, S. (1998). Fairbairn's object seeking: Between paradigms. In N. Skolnick \& D. Scharff (Eds.), Fairbairn, then \& now (pp. 115-135). Hillsdale, NJ: The Analytic Press.

National Association of Social Workers. (1996/2008). Code of ethics. Washington, DC: NASW

O'Connor, M. (1992). An Adlerian Approach to casework in a hospital setting. Social Worker, 60(2), 121-122.

Paris, B. (1994). Karen Horney: A psychoanalyst's search for selfunderstanding. London: Yale University Press.

Reid, W. (2002). Knowledge for direct social work practice: An analysis of trends. Social Service Review, 76, 6.

Seidler, R. (2013). Rivalry among children of the same family: Two cases from the guidance clinic of a teachers' association adviserDr. Alfred Adler. In A. Adler et al. (Eds.), Guiding the child (psychology revivals): On the principles of individual psychology (1st ed., pp. 183-193). Routledge. (Original work published in 1930).

Seidler, R., \& Zilah, L. (2013). The vienna child guidance clinics. In A. Adler et al. (Eds.), Guiding the child (psychology revivals): On the principles of individual psychology (1st ed., pp. 9-27). Routledge. (Original work published in 1930).

Sommers-Flanagan, J., \& Sommers-Flanagan, R. (2012). Counseling and psychotherapy theories in context and practice: Skills, strategies, and techniques. New York: Wiley.

Spiel, O., \& Birnbaum, F. (2013). The school and educational guidance. In A. Adler et al. (Eds.), Guiding the child (psychology revivals): On the principles of individual psychology (1st ed., pp. 66-83). Routledge. (Original work published in 1930).
Stein, H. (2014). Rediscovering Adler. Journal of Individual Psychology, 70(4), 273-276.

Todman, L., \& Mansager, E., (2011), Social justice: An Adlerian perspective and literature review. In UK 2011 Adlerian Yearbook, (pp. 91-100). Adlerian Society Publications, UK

Watts, R. E. (2000). Entering the new millennium: Is individual psychology still relevant? The Journal of Individual Psychology, 56(1), 21-27.

Watts, R. E., \& Pietrzak, D. (2000). Adlerian "encouragement" and the therapeutic process of solution-focused brief therapy. Journal of Counseling \& Development, 78(4), 442-447.

Wittels, F. (1939). The Neo-Adlerians. American Journal of Sociology., 45(3), 433-445.

Yura, M. (1983). Raising the child with special needs. The Journal of Adlerian Theory, Research \& Practice, 39(4), 369-379.

Zerner, T. (2013). The influence of individual psychology upon parents' associations. In A. Adler et al. (Eds.), Guiding the child (psychology revivals): On the principles of individual psychology (1st ed., pp. 84-88). Routledge. (Original work published in 1930).

Publisher's Note Springer Nature remains neutral with regard to jurisdictional claims in published maps and institutional affiliations.

Mary C. McCluskey DSW, LCSW is in private practice in New York City and teaches at New York University Silver School of Social Work. She is also a teacher and clinical supervisor in the psychodynamic program at The American Institute of Psychoanalysis. 